\title{
PENINGKATAN KETERAMPILAN BERPIKIR TINGKAT TINGGI IPA MELALUI MODEL PEMBELAJARAN DISCOVERY LEARNING
}

\section{IMPROVING HIGHER ORDER THINKING SKILLS IN SCIENCE THROUGH THE DISCOVERY LEARNING MODEL}

\author{
SUHARTATI
}

SDN Bleber 1 Yogyakarta

\section{Received: March 09, 2021 \\ Revised: September 30, 2021}

\section{Abstract} Higher order thinking skills (HOTS) are thinking processes that connect, manipulate, transform Accepted : November 26, 2021 improve high-order thinking skills (HOTS) in the content of science lessons through the discovery learning model for fourth grade students of SD Negeri Bleber 1 in the 2019/2020 school year. The subjects of this study were fourth grade students of SD Negeri Bleber 1 Prambanan having their address at Karanggede, Sumberharjo, Prambanan, Sleman, Yogyakarta Special Region. The type of research used is Classroom Action Research which lasts for two cycles, each cycle having two meetings. The data collection instruments used were direct observation and written tests. The data analysis technique used is descriptive analysis of improving science learning outcomes. The way to improve higher-order thinking skills is done by applying the discovey learning model. The learning implementation is based on the discovey learning cycle, namely giving, identifying problems, collecting data, processing data, and drawing conclusions. The average pre-test learning outcomes of science subject content class 55. In the first cycle the average science subject content class increased to 70 . In the second cycle the average science subject content class increased to 80. The results of pre-test learning completeness were the number of students who completed as many as 8 students (29\%). In the first cycle, the number of students who completed increased by 9 students (31\%) to 17 students (60\%). In cycle II, the number of students who completed increased by 7 students (26\%) to 24 (86\%). This shows that the implementation of the discovery learning model can improve the high-level thinking skills of fourth grade students at SD Negeri Bleber 1 Prambanan for the 2019/2020 school year.

\section{Abstrak}

Keterampilan berpikir tingkat tinggi (HOTS) merupakan proses berpikir yang menghubungkan, memanipulasi, mentransformasi pengetahuan, dan pengalaman yang dimiliki untuk memecahkan masalah dalam situasi yang baru. Penelitian yang dilakukan bertujuan untuk meningkatkan keterampilan berpikir tingkat tinggi (HOTS) muatan pelajaran IPA melalui model discovery learning pada peserta didik kelas IV SD Negeri Bleber 1 tahun ajaran 2019/2020. Subjek penelitian ini adalah peserta didik kelas IV SD Negeri Bleber 1 Prambanan yang beralamat di Karanggede, Sumberharjo, Prambanan, Sleman, Daerah Istimewa Yogyakarta. Jenis penelitian yang digunakan adalah Penelitian Tindakan Kelas yang berlangsung selama dua siklus, masing-masing siklus dua kali pertemuan. Instrumen pengumpulan data yang digunakan adalah pengamatan langsung dan tes tertulis. Teknik analisis data yang digunakan adalah analisis deskriftif peningkatan hasil belajar IPA. Adapun cara meningkatkan keterampilan berpikir tingkat tinggi dilakukan dengan menerapkan model pembelajaran discovey learning. Pelaksanaan pembelajaran berdasarkan siklus discovey learning yaitu pemberian, mengidentifikasi masalah, pengumpulan data, pengolahan data, dan menarik kesimpulan. Hasil belajar pre tes rata-rata kelas muatan pelajaran IPA 55. Pada siklus I rata-rata kelas muatan pelajaran IPA meningkat menjadi 70. Pada siklus II rata-rata kelas muatan pelajaran IPA meningkat menjadi 80. Hasil ketuntasan belajar pre tes jumlah peserta didik yang tuntas sebanyak 8 peserta didik (29\%). Pada siklus I, jumlah peserta didik yang tuntas meningkat 9 peserta didik (31\%) menjadi 17 peserta didik (60\%). Pada siklus II, jumlah peserta didik yang tuntas meningkat 7 peserta didik (26\%) menjadi 24 (86\%). Hal tersebut menununjukkan bahwa implementasi model pembelajaran discovey learning dapat meningkatkan keterampilan berpikir tingkat tinggi peserta didik kelas IV SD Negeri Bleber 1 Prambanan tahun ajaran 2019/2020.

Keywords: higher order thingking, science, and discovery learrning

Kata kunci: $\quad$ berpikir tingkat tinggi, IPA, dan discovery learning 


\section{PENDAHULUAN}

Sekolah dasar negeri (SDN) Bleber 1 melaksanakan pembelajaran tematik terpadu sesuai dengan tuntutan Kurikulum 2013, yaitu dengan mengintegrasikan beberapa muatan pelajaran dalam satu pembelajaran. Beberapa muatan, misalnya Bahasa Indonesia dan ilmu pengetahuan alam (IPA) disatukan dalam satu tema yang sama selanjutnya disajikan dalam satu pembelajaran utuh yang saling berkaitan.

Pelaksanaan pembelajaran Kurikulum 2013 yang guru lakukan menggunakan acuan buku peserta didik dan buku guru dari Kementerian Pendidikan dan Kebudayaan (Kemendikbud) Republik Indonesia. Buku tersebut sudah sesuai dan layak digunakan dalam pembelajaran karena diterbitkan oleh Kementerian Pendidikan dan Kebudayaan. Fakta di lapangan, guru mengalami beberapa kesulitan seperti materi dan tugas tidak sesuai dengan lingkungan peserta didik. Selain itu, fokus guru dalam pembelajaran adalah dimensi penguasaan pengetahuan kognitif yang lebih menekankan pada hafalan materi. Proses berpikir yang berkembang dalam diri peserta didik masih dalam level C1 (mengingat), memahami (C2), dan C3 (aplikasi). Guru hanya kadang-kadang melaksanakan pembelajaran yang memiliki orientasi untuk meningkatkan keterampilan berpikir tingkat tinggi Higher Order Thinking Skills (HOTS). Peran media pembelajaran sangat penting namun jarang digunakan oleh guru seperti pendapat Arsyad bahwa kejenuhan belajar peserta didik dapat diatasi dengan menggunakan media pembelajaran yang tepat dan bervariasi (Arsyad 2014).

Hasil rata-rata ulangan harian peserta didik SDN Bleber 1 kelas IV muatan pelajaran IPA yang dilaksanakan tanggal 30 Agustus 2019 menunjukkan bahwa masih banyak peserta didik yang memperoleh nilai di bawah Kriteria Ketuntasan Minimal (KKM). Sebanyak 17 dari 28 peserta didik (61\%) belum mencapai KKM. Sedangkan yang bisa mencapai KKM hanya 11 dari 28 peserta didik (39\%). Hal ini membuat guru perlu melakukan perbaikan dalam pembelajaran agar hasil belajar peserta didik mengalami peningkatan.

Wawancara yang dilakukan menunjukkan hasil bahwa peserta didik jenuh mengikuti pembelajaran yang dilakukan guru dengan metode ceramah dan penugasan. Ceramah yang dilakukan guru bersifat teoritis dan hanya sekedar menyampaikan materi yang ada dalam buku. Metode penugasan yang dilaksanakan guru berupa daftar pertanyaan tertulis dimana jawaban pertanyaan ada dalam buku peserta didik.

Era revolusi industri 4.0 menuntut manusia untuk berpikir kritis dan inovatif. Peserta didik hendaknya sejak dini belajar berpikir kritis dan inovatif agar memiliki HOTS. Peserta didik yang memiliki keterampilan HOTS tentunya dapat mengerjakan soal yang beragam ataupun inovatif. Seperti yang dipaparkan King, Goodson, dan Rohani F bahwa HOTS terdiri atas berpikir kritis, logis, reflektif, metakognitif, dan kreatif (King 2004).

Model pembelajaran yang berorientasi pada HOTS dan disarankan dalam implementasi Kurikulum 2013 adalah model penemuan discovery learning. Model ini digunakan karena dapat mengembangkan cara belajar aktif dengan menemukan dan menyelidiki secara mandiri maka hasil yang diperoleh akan bertahan lama dalam ingatan sehingga tidak mudah dilupakan oleh peserta didik (Kristin 2016).

Pembelajaran discovery learning didesain sedemikian rupa agar peserta didik dapat menemukan konsep, arti, dan hubungan dengan proses mentalnya sendiri. Kegiatan yang dilakukan peserta didik untuk memahami konsep, arti, dan hubungan dilakukan dengan cara mengamati, menggolongkan, menarik dugaan, menjelaskan, dan membuat kesimpulan. Model discovery learning memiliki fokus pada aktivitas peserta didik ketika belajar. Guru memiliki peran sebagai pembimbing dan fasilitator yang menyediakan fasilitas bagi peserta didik agar mudah dalam mengikuti pembelajaran (Asturi W 2018). Pada akhirnya peserta didik akan menemukan konsep, arti, hubungan, dan kesimpulan dari materi yang dipelajari.

Beberapa hasil penelitian memaparkan bahwa pembelajaran discovery learning dapat meningkatkan HOTS siswa. Penelitian pertama oleh IImi Zajuli Ichsan menunjukkan bahwa melalui video berbasis kasus penemaran lingkungan dapat meningkatkan keterampilan berpikir tingkat tinggi (Zajuli 2018). Penelitian kedua oleh (Purileila 2016) menunjukkan bahwa model discovery learning dapat meningkatkan perilaku tanggung jawab.

Berdasarkan permasalahan, maka dilakukan penelitian tindakan kelas menerapkan model 
pembelajaran discovery learning untuk meningkatkan keterampilan HOTS peserta didik kelas IV SDN Bleber 1. Penelitian ini memiliki tujuan untuk meningkatkan aktivitas peserta didik dalam skema HOTS. Diharapkan penelitian ini dapat memberikan manfaat alternatif pilihan model pembelajaran yang dapat dipakai guru untuk meningkatkan HOTS peserta didik.

\section{METODE PENELITIAN}

Penelitian ini menggunakan metode penelitian tindakan kelas (PTK) yang dikembangkan oleh Kemmis, Mc. Taggart. Dan Nixon yang terdiri atas perencanaan, pelaksanaan, observasi, dan refleksi (Kemmis 2013). Hasil refleksi menjadi dasar melaksanakan perencanaan ulang siklus berikutnya. PTK ini dilaksanakan di SDN Bleber 1 dengan subjek peserta didik kelas IV tahun ajaran 2019/2020.

PTK ini dilaksanakan bulan September sampai Oktober 2019 selama dua siklus. Siklus pertama dilaksanakan sebanyak dua kali pertemuan dengan materi perubahan bentuk energi. Siklus kedua dilaksanakan sebanyak dua kali pertemuan dengan materi yang sama dengan siklus pertama, yaitu perubahan bentuk energi. Subjek PTK adalah peserta didik kelas IV SD Negeri Bleber 1 Prambanan semester 1 tahun ajaran 2019/2020 sebanyak 17 peserta didik laki-laki dan 11 peserta didik perempuan. Kegiatan pembelajaran yang dilakukan dengan dibantu guru kelas III sebagai observer. Materi IPA dalam PTK ini adalah perubahan bentuk energi yang dilaksanakan sacara bersamaan dengan kegiatan pembelajaran tematik mata pelajaran yang lain.

Metode pengumpulan data dalam PTK ini meliputi observasi, tes, dan dokumentasi. Observasi yang dilakukan untuk mengamati keterlaksanaan peserta didik penerapan model pembelajaran discovery learning dalam meningkatkan HOTS. Observasi PTK dilaksanakan oleh observer guru kelas III dengan menggunakan lembar observasi. Tes yang dilakukan untuk mengukur keterampilan berpikir tingkat tinggi (HOTS) berbentuk pilihan ganda sesuai pendapat (Treagust 2006) bahwa soal pilihan ganda dapat mengukur kemampuan kognitif peserta didik pada level yang lebih tinggi dengan kategori soal tes C4, C5, dan C6. Dokumentasi digunakan sebagai pelengkap untuk mengumpulkan data.

Teknik deskriptif kualititatif dan non parametik dilakukan peneliti untuk mengolah data hasil PTK. Data deskriptif kualitatif diolah dalam bentuk kalimat meliputi tahap reduksi data, penyajian data, dan penarikan kesimpulan. Pengolahan data non parametrik disajikan berupa angka hasil belajar peserta didik berdasarkan ketuntasan individu, klasikal, dan rata-rata kelas.

Setiap siklus dalam PTK ini terdiri atas dua kali pembelajaran. Materi pembelajaran yang ada dalam setiap siklus sama. Pada tahap refleksi dilakukan untuk menganalisis kelebihan dan kekurangan untuk menciptakan pembelajaran yang lebih baik. Pada akhir pembelajaran kedua, peserta didik akan mengerjakan tes akhir untuk mengukur ketercapaian HOTS. PTK ini dikatakan berhasil jika memenuhi dua indikator keberhasilan, yaitu peningkatan rata-rata hasil belajar IPA dan ketuntasan belajar klasikal U75\%. Jika pada akhir siklus belum memenuhi indikator keberhasilan, maka akan dilaksanakan siklus berikutnya dengan melakukan refleksi terlebih dahulu.

\section{HASIL DAN PEMBAHASAN}

Langkah awal terlebih dahulu melakukan pretes pada hari senin tanggal 18 September 2019. Soal pretest berkaitan dengan materi perubahan bentuk energi dengan kategori soal C4, C5, dan C6. Siklus I kegiatan pembelajaran berlangsung selama dua kali pertemuan berorientasi tematik sehingga berlangsung selama satu hari yaitu pembelajaran muatan IPA yang terpadu dengan bahasa Indonesia.

Siklus I pertemuan pertama dilaksanakan pada hari Sabtu tanggal 21 September 2019 dengan materi perubahan energi panas menjadi gerak. Kegiatan pembelajaran dengan mengajak peserta didik berdiskusi dan bekerjasama membuat lampion. Guru memberikan LKS yang berisi teks petunjuk langkah-langkah membuat lampion dan soal yang perlu di diskusikan. Peserta didik secara berkelompok membaca teks petunjuk langkah-langkah pembuatan lampion. Guru menjelaskan petunjuk yang harus dilakukan oleh peserta didik dengan menyiapkan alat dan bahan untuk membuat lampion.

Peserta didik membuat lampion dengan semangat dan sebagian aktif bekerjasama membuat lampion. Beberapa bimbingan yang diberikan guru saat pembuatan lampion berlangsung yaitu menunggu lem kering di sedotan plastik baru bisa mengelem plastik kresek, bisa menggunakan 
selotip jika lem yang digunakan habis, dan mengelem lilin pada kertas, serta himbauan kerjasama kelompok. Selesai membuat lampion setiap kelompok dimiinta untuk mencoba menghidupkan lampion. Kelompok yang kesulitan menghidupkan lampion mendapat bantuan guru. Ketika lampion dinyalakan, peserta didik memperhatikan hal-hal yang terjadi. Lampion dapat menggembung dan terasa panas. Tak lama kemudian bagian atas dan samping plastik kresek atau lampion meleleh. Hasil diskusi diperoleh kesimpulan yaitu terjadi perubahan energi panas ke energi gerak. Untuk mengatasi lampion yang meleleh atau rusak yaitu dengan menggunakan ukuran plastik yang lebih besar dan lilin yang digunakan tidak besar.

Selanjutnya pertemuan kedua siklus I dilaksanakan pada hari Rabu 25 September 2019 dengan materi perubahan energi kimia menjadi energi listrik. Kegiatan pembelajaran dengan melakukan percobaan membuktikan energi listrik dari kentang. Untuk memudahkan dalam melakukan percobaan, guru menuliskan langkah-langkah percobaan pada lembar kerja. Peserta didik mempersiapkan alat dan bahan dalam melakukan percobaan. Pada saat percobaan ditemukan beberapa kendala yaitu, kesulitan menancapkan koin uang logam di kentang, salah menyambung kabel (kabel uang logam di sambung dengan uang logam), dan salah memasang lampu led. Setiap kelompok mendiskusikan perbedaan dan persamaan hasil menulis langkah- langkah melakukan percobaan energi alternatif dari kentang dengan tahapan yang terdapat dalam LKS. Sebagian besar peserta didik memaparkan bahwa langkah-langkah percobaan yang mereka tulis masih kurang jelas dan sistematis.

Setelah selesai melakukan seluruh tahapan percobaan selanjutnya membuat kesimpulan materi yang telah dipelajari hari ini, yaitu kentang bisa menjadi sumber energi listrik. Peserta didik melakukan refleksi pembelajaran dari percobaan yang telah dilakukan yaitu menemukan sumber energi alternatif dari kentang. Di akhiri dengan penguatan dari guru tentang materi yang telah dipelajari dengan mengaitkan pada penerapan dalam kehidupan sehari-hari.

Siklus II dilaksanakan selama dua kali pertemuan yaitu pada hari Sabtu, 5 Oktober 2019 dilaksanakan pertemuan pertama siklus II dengan materi yang sama dengan siklus I pertemuan pertama, yaitu perubahan energi panas menjadi gerak. Guru menjelaskan bahwa pembelajaran dilakukan dengan berdiskusi dan bekerjasama membuat lampion dan dibantu dengan lembar kerja yang berisi teks petunjuk langkah-langkah membuat lampion dan soal yang perlu di diskusikan. Peserta didik secara berkelompok membaca teks petunjuk langkah-langkah pembuatan lampion dan bertanya jika ada hal-hal yang belum jelas. Peserta didik juga harus menyiapkan alat dan bahan yang dibutuhkan dalam pembuatan lampion. Pembuatan lampion dilakukan secara berkelompok dan guru melakukan pengamatan selama proses berlangsung.

Petemuan kedua siklus II pada Rabu, 9 Oktober 2019 dengan materi yang sama dengan siklus I pertemuan 2, yaitu perubahan energi kima menjadi energi listrik. Kegiatan pembelajaran yaitu menemukan sumber energi alternatif melalui percobaan dan membandingkan teks petunjuk percobaan energi alternatif. Kegiatan pembelajaran dengan melakukan percobaan untuk menemukan sumber alternatif dengan menggunakan makanan. Bahan makanan yang disiapkan yaitu pisang, belimbing wuluh, jambu air, dan jeruk nipis. Setiap kelompok membawa satu jenis bahan makanan ada yang membawa dua jenis bahan makanan. Dalam melakukan percobaan dipandu dengan lembar kerja yang berisi teks petunjuk langkah-langkah percobaan. Peserta didik diminta untuk membaca teks petunjuk yang telah disiapkan oleh guru dan dapat menanyakan jika ada hal-hal yang belum dimengerti.

Dari hasil percobaan yang telah dilakukan diperoleh kesimpulan bahwa makanan dapat menjadi sumber energi listrik dan menjadi sumber energi alternatif jika sumber energi utama tidak ada atau habis. Guru memberikan penguatan bahwa materi yang telah dipelajari dapat diterapkan dalam kehidupan sehari-hari.

Pembahasan dalam penelitian ini berdasarkan atas hasil dan catatan yang dilakukan dari seluruh rangkaian tiap siklus dengan dibantu oleh observer. Pada pertemuan pertama pada siklus I peserta didik melakukan percobaan membuat lampion secara terburu-buru, bahan yang digunakan untuk membuat lampion hanya cukup untuk satu kali percobaan, dan guru kurang dalam melakukan perannya sebagai fasilitator. Hasil percobaan tidak sesuai dengan yang diharapkan, peserta didik merasa kecewa dan tidak bisa membuat lampion lagi.

Pada pertemuan pertama siklus II, peserta didik melakukan percobaan membuat lampion dengan 
lebih terarah dan tidak terburu-buru karena guru melakukan perannya sebagai fasilitator dengan baik. Sebelum peserta didik melakukan percobaan, guru memberikan penjelasan dan contoh cara membuat lampion dengan jelas. Penataan tempat duduk kelompok di pinggir kelas sehingga guru mudah untuk melakukan pengawasan dan pembimbingan kepada peserta didik. Peserta didik yang gagal membuat lampion dengan bimbingan guru melakukan evaluasi dan berusaha membuat lampion lagi hingga waktu pembelajaran selesai.

Perbedaan pertemuan kedua pada siklus I dan siklus II, yaitu pada siklus I peserta didik hanya menggunakan bahan kentang sebagai sumber energi kimia, sedangkan pada siklus II peserta didik berinisiatif menggunakan berbagai bahan makanan sekitar lingkungan tempat tinggal mereka sebagai sumber energi kimia.

Berdasarkan hasil tes akhir peserta didik kelas IV SD Negeri Bleber 1 tahun ajaran 2019/2020 peningkatan HOTS muatan pelajaran IPA dengan model pembelajaran discovery learning secara lebih jelas terlihat pada tabel berikut.

Tabel 1. Perbandingan Pretes, posttes siklus I, dan posttes siklus II

\begin{tabular}{lcccccc}
\hline \multirow{2}{*}{ Kategori } & \multicolumn{2}{c}{ Pre tes } & \multicolumn{2}{c}{ Post Tes siklus I } & \multicolumn{2}{c}{$\begin{array}{c}\text { Post Tes siklus } \\
\text { II }\end{array}$} \\
\cline { 2 - 8 } & \multicolumn{1}{c}{$\boldsymbol{\Sigma}$} & $(\%)$ & $\Sigma$ & $(\%)$ & $\Sigma$ & $(\%)$ \\
\hline Tuntas & 8 & 29 & 17 & 60 & 24 & 86 \\
Belum Tuntas & 20 & 71 & 11 & 40 & 4 & 14 \\
\hline Rata-rata & \multicolumn{2}{c}{55} & & 70 & \multicolumn{2}{c}{80} \\
\hline
\end{tabular}

Berdasarkan tabel 1 hasil pre test menunjukkan bahwa 28 peserta didik yang mengerjakan soal pretest hanya 8 peserta didik (29\%) peserta didik yang tuntas. Peserta didik sebanyak 20 (71\%) belum tuntas. Rata-rata kelas IV sangat rendah yaitu 55.

Pada post test siklus I menunjukkan peningkatan. Sebanyak 28 peserta didik, terdapat 17 peserta didik (60\%) yang tuntas belajar dan 11 peserta didik (40\%) yang belum tuntas belajar. Rata-rata hasil belajar siklus I menunjukkan nilai 70. Dalam penelitian ini, indikator keberhasilan ditetapkan ketuntasan belajar klasikal U75\%. Hal ini artinya siklus I belum berhasil karena belum memenuhi indikator keberhasilan yang ditetapkan. Berdasarkan refleksi yang dilakukan peneliti, hasil belajar peserta didik tidak mencapai indikator keberhasilan karena guru kurang memfasilitasi peserta didik untuk melakukan kegiatan evaluasi dan mencipta sedangkan pembelajaran HOTS dapat diukur dengan menyesuaikan taksonomi Anderson meliputi menganalisis, mengevaluasi, dan mencipta. Pada siklus I, peserta didik hanya melakukan satu kali percobaan dengan alat dan bahan yang terbatas, sehingga kemampuan peserta didik dalam mengevaluasi dan mencipta hal baru kurang maksimal.

Pada postes siklus II menunjukkan peningkatan dibandingkan siklus I. Diketahui bahwa dari 28 peserta didik terdapat 24 peserta didik (86\%) yang mencapai ketuntasan belajar dan 4 peserta didik (14\%) belum mencapai ketuntasan belajar. Rata-rata hasil belajar siklus II mencapai nilai 80. Dalam penelitian ini, indikator keberhasilan ditetapkan yaitu hasil belajar peserta didik mencapai ketuntasan belajar klasikal U75\%. Hal ini menunjukkan tindakan siklus II berhasil karena mencapai indikator keberhasilan yang ditetapkan.

Peningkatan hasil siklus I dan siklus II ini sejalan dengan pendapat (Heong 2011) bahwa peserta didik yang dilatih dengan berpikir tingkat tinggi menunjukkan dampak positif pada pengembangan pembelajaran mereka. Dengan demikian permasalahan yang dihadapi guru dapat terselesaikan melalui penelitian ini. Pada siklus II rata-rata nilai peserta didik kelas IV SD Negeri Bleber 1 tahun pelajaran 2019/2020 muatan pelajaran IPA meningkat menjadi 80 dan jumlah peserta didik yang termasuk kategori tuntas meningkat menjadi 24 (86\%). Penerapan pembelajaran discovery learning dapat meningkatkan HOTS peserta didik kelas IV SD Negeri Bleber 1 tahun ajaran 2019/2020. Hal ini didukung oleh penelitian (Alisa 2018) bahwa ada pengaruh terhadap hasil belajar peserta didik kelas $\checkmark$ dengan menggunakan model pembelajaran discovery learning. Dijelaskan lebih lanjut oleh (Ariyana 2019) model pembelajaran discovery learning adalah model pembelajaran yang mengembangkan kemampuan peserta didik memahami konsep, arti, dan hubungan yang dilakukan dengan proses intuitif yang pada ujungnya sampai pada suatu kesimpulan, karena usaha menarik kesimpulan adalah bagian dari pengembangan HOTS. 


\section{SIMPULAN DAN SARAN}

Implementasi model pembelajaran discovery learning dapat meningkatkan kemampuan HOTS peserta didik kelas IV SDN Bleber 1 tahun ajaran 2019/2020. Hal ini dibuktikan dengan peningkatan nilai rata-rata atau ketuntasan klasikal hasil belajar IPA dari pre tes ke siklus I dan ke siklus II. Peserta didik diharapkan dapat menerapkan kemampuan berpikir tingkat tinggi dalam belajar, tidak terbatas menghafal dan mengerjakan soal latihan berkali-kali. Kemampuan belajar dengan cara ini dapat membantu peserta didik menguasai materi secara lebih bermakna dan mendalam.

Dari simpulan dapat disarankan model pembelajaran discovery learning dengan menerapkan keterampilan berpikir tingkat tinggi dapat lebih dikembangkan sesuai dengan muatan pelajaran atau materi pelajaran lain agar kemampuan HOTS peserta didik semakin terasah dan tercipta pembelajaran yang lebih bermakna sehingga diharapkan dapat berdampak pada peningkatan mutu pembelajaran di sekolah.

\section{PUSTAKA ACUAN}

Alisa, Pitri. Pengaruh Penerapan Model Pembelajaran Discovery Learning terhadap hasil belajar peserta didik kelas V SD. Bandar Lampung: Universitas Lampung, 2018.

Ariyana, Yoki dkk. Buku Pegangan Pembelajaran Berorientasi Pada Keterampilan Berpikir tingkat tinggi. Jakarta: Kementerian Pendidikan dan Kebudayaan, 2019.

Arsyad. Media Pembelajaran . Jakarta: Rajawali Pers, 2014.

Asturi W. Peran Guru sebagai Fasilitator dalam Pelaksanaan Pembelajaran Efektif pada Mata Pelajaran Ekonomi Madrasah Aliyah Al Islam Rumbio. Riau: Universitas Negeri Sultan Syarif Kasim, 2018.

Heong, dkk. "The Level of Marzano Higher Order Thinking Skills Among Technical Education Students." International Jurnal of Social Science and Humanity, 2011.

Kemmis, Mc Taggart, R \& Nixon, R. The Action research Planner: Doing critical participatory action research. Springer Science \& Business Media, 2013.

King, F.J. Goodson, L, Rohani F. Higher Order Thingking Skill . Center for Advanceent of Learning and Assessment, 2004.

Kristin, F. "Analisis Model Pembelajaran Discovery Learning dalam Meningkatkan Hasil Belajar SIswa SD." Jurnal Pendidikan Dasar Perkhasa, 2016: 90-98.

Purileila. Pengaruh Penggunaan Model Discovery Learning dan Model Konvensional untuk Meningkatkan Perilaku TanggungJawab pada Pembelajaran PKN Siswa Kelas VIII SMP Negeri 19 Bandar Lampung. Lampung: Universitas Lampung, 2016.

Treagust, David F. "Diagnostic Assesment in Science as A Means to Improving Teaching, Learning and Retention." Uniserve Science Assessment Symposium Proceedings. Sydney, 2006.

Zajuli, Ilmi. "Keterampilan Berpikir tingkat tinggi melalui video berbasis kasus pencemaran lingkungan." Edu, 2018. 